\title{
Blood Pressure and Depressive Symptoms
}

\author{
Yongpin $\mathrm{Mu}^{1 *}$, Yongqing $\mathrm{Gao}^{2 *}$, Wenjie Sun ${ }^{2,3 \#}$ \\ ${ }^{1}$ Department of Clinical Laboratory Centre, The Affiliated People's Hospital of Inner Mongolia Medical \\ University, Hohhot, China \\ ${ }^{2}$ School of Food Science, Guangdong Pharmaceutical University, Guangzhou, China \\ ${ }^{3}$ School of Public Health and Tropical Medicine, Tulane University, New Orleans, USA \\ Email: "wsun3@tulane.edu
}

Received August $7^{\text {th }}$, 2013; revised September $8^{\text {th }}, 2013$; accepted October $10^{\text {th }}, 2013$

Copyright (C) 2013 Yongpin Mu et al. This is an open access article distributed under the Creative Commons Attribution License, which permits unrestricted use, distribution, and reproduction in any medium, provided the original work is properly cited.

The topic of blood pressure and depression is an old question. Depression is common in the elderly population (Sun, Schooling, Chan, Ho, \& Lam, 2011). Although several epidemiologic studies have assessed the relationship between low blood pressure and depressive symptoms in geriatric populations, the results have been inconsistent. Depressive symptoms used to be been considered a risk factor associated with development of hypertension (Hildrum, Romild, \& Holmen, 2011). Recently, additional evidence showed that depressive symptoms are associated with low blood pressure (Licht et al., 2009; Scuteri et al., 2009). These results suggest a complicated association between blood pressure and depression. It is possibly a "U" shaped response, with too low or too high systolic blood pressure both associated with depression (Barrett-Connor \& Palinkas, 1994).

This relationship leads to the question: does depression cause the reduced blood pressure or does a reduced blood pressure cause the depression? It is plausible that low blood pressure results in depressive symptoms in the elderly. A prospective community-based study found that low blood pressure can predict the depression (Siennicki-Lantz, Andre-Petersson, \& Elmstahl, 2013). Depressive symptoms could be predicted by hypertension earlier in life, and were strongly associated with decreasing Systolic blood pressure (SBP) during the last decade (Siennicki-Lantz, Andre-Petersson, \& Elmstahl, 2013). However, the link between blood pressure and depression could be reversed (Heckbert et al., 2010; Hildrum, Mykletun, Holmen, \& Dahl, 2008; Lenoir et al., 2008). Moreover, Paterniti et al. point out that low blood pressure was a risk factor for, but not a consequence of, increasing depressive symptoms (Paterniti, Verdier-Taillefer, Geneste, Bisserbe, \& Alperovitch, 2000). One plausible mechanism to explain this correlation is that there is one gene from the ancestor that affects both blood pressure and depression.

There are many confounding factors that can affect the correlation in depression and blood pressure. The relationship also can be explained by other factor such as the health status, previous diseases, and post-traumatic stress (Kamphuis et al., 2008; Scuteri, 2008; Signorelli, Costanzo, Cinconze, \& Concerto, 2013). Pre-existing diseases like cardiovascular disease, especially heart diseases such as stroke, may affect both blood

\footnotetext{
${ }^{*}$ These authors contributed equally to this work.

${ }^{\#}$ Corresponding author.
}

pressure and depression. In this hypothesis blood pressure and depression are both related to another factor. New research has found that frontal-striatal white matter integrity may be the anatomical region through which blood pressure confers vulnerability to depression (Hoptman et al., 2008). There is a negative relationship between SBP and depression in the group of people whose functional ability is normal, but no relationship exists in people with moderately or severely damaged white matter.

Functional changes in this region from pre-existing diseases can affect the relationship between blood pressure and depression.

Without a large sample size community-based perspective study, it is not easy to draw a conclusion on the relationship between blood pressure and depression. As Mark Twain said, "supposing is good, but finding out is better". In order to figure out the relationship, further research will be required to clarify causal pathways, in particular: 1) whether low blood pressure and depression are both secondary to previous diseases; and/or 2) whether low blood pressure is a marker for other, more psychological risk factors for depression, such as the impact of poor physical health and functional limitation (Stewart, 2000).

\section{REFERENCES}

Barrett-Connor, E., \& Palinkas, L. A. (1994). Low blood pressure and depression in older men: A population based study. BMJ, 308, 446449.

Heckbert, S. R., Rutter, C. M., Oliver, M., Williams, L. H., Ciechanowski, P., Lin, E. H., \& Von Korff, M. (2010). Depression in relation to long-term control of glycemia, blood pressure, and lipids in patients with diabetes. Journal of General Internal Medicine, 25 524-529. http://dx.doi.org/10.1007/s11606-010-1272-6

Hildrum, B., Mykletun, A., Holmen, J., \& Dahl, A. A. (2008). Effect of anxiety and depression on blood pressure: 11-year longitudinal population study. The British Journal of Psychiatry, 193, 108-113. http://dx.doi.org/10.1192/bjp.bp.107.045013

Hildrum, B., Romild, U., \& Holmen, J. (2011). Anxiety and depression lowers blood pressure: 22-year follow-up of the population based HUNT study, Norway. BMC Public Health, 11, 601. http://dx.doi.org/10.1186/1471-2458-11-601

Hoptman, M. J., Gunning-Dixon, F. M., Murphy, C. F., Ardekani, B. A., Hrabe, J., Lim, K. O., \& Alexopoulos, G. S. (2008). Blood pressure and white matter integrity in geriatric depression. Journal of Affective Disorders, 115, 171-176.

Kamphuis, M. H., Geerlings, M. I., Giampaoli, S., Nissinen, A., Grob- 
bee, D. E., \& Kromhout, D. (2008). The association of depression with cardiovascular mortality is partly explained by health status. The FINE study. Journal of Affective Disorders, 114, 184-192.

Lenoir, H., Lacombe, J. M., Dufouil, C., Ducimetiere, P., Hanon, O., Ritchie, K., \& Tzourio, C. (2008). Relationship between blood pressure and depression in the elderly. The three-city study. Journal of Hypertension, 26, 1765-1772.

http://dx.doi.org/10.1097/HJH.0b013e3283088d1f

Licht, C. M., de Geus, E. J., Seldenrijk, A., van Hout, H. P., Zitman, F. G., van Dyck, R., \& Penninx, B. W. (2009). Depression is associated with decreased blood pressure, but antidepressant use increases the risk for hypertension. Hypertension, 53, 631-638.

http://dx.doi.org/10.1161/HYPERTENSIONAHA.108.126698

Paterniti, S., Verdier-Taillefer, M. H., Geneste, C., Bisserbe, J. C., \& Alperovitch, A. (2000). Low blood pressure and risk of depression in the elderly. A prospective community-based study. The British Journal of Psychiatry, 176, 464-467.

http://dx.doi.org/10.1192/bjp.176.5.464

Scuteri, A. (2008). Depression and cardiovascular risk: Does blood pressure play a role? Journal of Hypertension, 26, 1738-1739. http://dx.doi.org/10.1097/HJH.0b013e32830dfff7

Scuteri, A., Spalletta, G., Cangelosi, M., Gianni, W., Assisi, A., Bran- cati, A. M., \& Volpe, M. (2009). Decreased nocturnal systolic blood pressure fall in older subjects with depression. Aging Clinical and Experimental Research, 21, 292-297.

http://dx.doi.org/10.1007/BF03324918

Siennicki-Lantz, A., Andre-Petersson, L., \& Elmstahl, S. (2013). Decreasing blood pressure over time is the strongest predictor of depressive symptoms in octogenarian men. The American Journal of Geriatric Psychiatry, 21, 863-871.

http://dx.doi.org/10.1016/j.jagp.2012.11.007

Signorelli, M. S., Costanzo, M. C., Cinconze, M., \& Concerto, C. (2013). What kind of diagnosis in a case of mobbing: Post-traumatic stress disorder or adjustment disorder? BMJ Case Reports.

http://dx.doi.org/10.1136/bcr-2013-010080

Stewart, R. (2000). Low blood pressure and depression in the elderly. The British Journal of Psychiatry, 177, 181-182.

http://dx.doi.org/10.1192/bjp.177.2.181-b

Sun, W., Schooling, C. M., Chan, W. M., Ho, K. S., \& Lam, T. H. (2011). The association between depressive symptoms and mortality among Chinese elderly: A Hong Kong cohort study. The Journals of Gerontology: Series A, 66, 459-466.

http://dx.doi.org/10.1093/gerona/glq206 